\title{
Walnuts: Calendar of Operations for Home Gardeners
}

\author{
Pamela M. Geisel is UC Cooperative Extension Farm Advisor in Environmental Horticulture for \\ Fresno County; Carolyn L. Unruh is UCCE staff writer for Fresno County; and Paul Vossen is \\ UCCE Farm Advisor in Fruits, Vegetables, and Marketing for Sonoma and Marin Counties.
}

Walnuts make lovely shade trees, in addition to producing a delightful nut. Various types of walnuts are grown in California, but the most popular are the English varieties. They have a moderate chilling requirement of about 500 to 1,000 hours. Shoots and flowers of the early varieties can be damaged by late spring frosts in cold areas. They do best in deep, welldrained, medium-textured soils. Walnut trees require regular irrigation for a quality nut crop, but once established they can tolerate periods of drought. They generally do poorly when planted in lawns: frequent irrigations promote root diseases to which walnut trees are susceptible.

\section{Winter Dormant Season}

1.Prune mature trees by thinning out limbs in crowded parts of the canopy to let light into the whole tree. Remove broken and dead branches.

2.Remove and destroy old nuts on trees and on the ground to kill resident larvae of codling moths and navel orangeworms and to help reduce damage from these insects the following year.

\section{Spring Bloom Season}

1.Spray for blossom blight when female flowers appear (they appear as tiny green nuts with feathery pistils) and at 10- to 14-day intervals until rainy weather stops. Use bordeaux or another fixed-copper material and provide thorough coverage of the whole tree. Blossom blight appears in June as black discoloration at the blossom end of nuts, and later as black, hollow nuts.

2.If scale is a problem, monitor the scale population and treat with narrow-range oil when the crawlers appear. Do not apply oil when temperatures go above $90^{\circ} \mathrm{F}$, and do not use it in trees that have been stressed by drought, heavy scale populations, or other factors. Irrigate the trees well prior to oil application.

3. Remove all weeds from around the base of the trees, and keep this area dry in summer to reduce root and crown rot problems.
4.Fertilize mature trees with about 8 to 10 pounds of ammonium sulfate (depending upon tree size) just before or during a rain or the first irrigation.

5.In very hot regions, paint the trunks and lower branches of newly planted young trees with a 1:1 mixture of white interior latex paint and water to prevent sunburn injury and to reduce borer infestations.

\section{Summer Growing Season}

1.To reduce the incidence of codling moth and navel orangeworm in the current growing season, gather and destroy any damaged immature nuts that fall to the ground or remain on the tree. Clean-up is especially important in May and June.

2.If you use drip irrigation, apply just the amount of water needed to replace what is used by the tree and lost from the soil through evaporation. If you use sprinkler or flood irrigation, water about every three to four weeks during the summer months. Young, small trees will need about 4 to 12 gallons of water per day, and large trees about 30 to 50 gallons per day. In garden settings some of this demand is usually met by water applied to nearby plants. Water requirements will vary depending on your soil type and environmental conditions. Irrigate at the drip line, well away from the trunk of the tree.

3.Walnut husk fly larvae may cause considerable damage to the green outer hull of walnuts, but rarely do they affect the kernels inside the shells. If walnut husk fly attacks have a history as a recurring problem, spray with malathion at 21day intervals beginning about August 1. The effectiveness of walnut husk fly sprays is significantly increased if you add molasses to the spray at 1 to 1.5 times the amount of malathion. For example, if the label recommends 2 teaspoons per gallon of malathion, add 3 teaspoons of molasses as well. Always follow the label-recommended rates for malathion and other chemicals. When using a malathion-molasses mix, it is generally sufficient to spray just the lower $1 / 3$ to $1 / 2$ of the tree. 
Autumn

1. To keep worm damage to a minimum, harvest nuts as early as possible. Shake or pole the trees when the green hulls begin to crack and separate from the shells. Remove the hulls as soon as possible after harvesting and discard them. Wear gloves to avoid staining your hands.

2. Place the hulled walnuts in a warm, well-ventilated area to dry. Store in-shell nuts in a cool, dry place in sealed plastic bags after they have been frozen for a few days to kill any insect eggs that may have been present. You can shell walnuts when the kernels have dried enough so that they break easily when bent. Shelled nuts may be stored for several months to a year in the refrigerator or freezer. In general, storage life for shelled nuts is shorter at room temperature than in a refrigerator or freezer.

\section{For More Information}

Cousult these UC IPM Pest Notes online at

http: / / www.ipm.ucdavis.edu:

Aphids

Bordeaux Mixture

Codling Moth

Scales

Spider Mites

Walnut Husk Fly

You'll also find detailed information on many aspects of fruit and nut tree care in these titles and in other publications, slides sets, and videos from UC ANR:
California Master Gardener Handbook, publication 3382

Drip Irrigation in the Home Landscape, publication 21579

Pests of the Garden and Small Farm, publication 3332

Pruning Fruit and Nut Trees, publication 21171

Sweet Cherries for the Home Grounds, publication 2951

The UC Guide to Solving Garden and Landscape Problems, CD-ROM 3400

\section{ORDERING}

To order these products, visit our online catalog at http: / / anrcatalog.ucdavis.edu. You can also place orders by mail, phone, or fax, or request a printed catalog of publications, slide sets, and videos from

University of California

Agriculture and Natural Resources

Communication Services

6701 San Pablo Avenue, 2nd Floor

Oakland, California 94608-1239

Telephone: (800) 994-8849 or (510) 642-2431

FAX: (510) 643-5470

E-mail inquiries: danrcs@ucdavis.edu

For a free catalog of other publications, telephone (800) 994-8849.

Visit the ANR Communication Services website at http: / / anrcatalog.ucdavis.edu.

Publication 7263

(C) 2002 by the Regents of the University of California, Division of Agriculture and Natural Resources. All rights reserved.

The University of California prohibits discrimination against or harassment of any person employed by or seeking employment with the University on the basis of race, color, national origin, religion, sex, physical or mental disability, medical condition (cancer-related or genetic characteristics), ancestry, marital status, age, sexual orientation, citizenship, or status as a covered veteran (special disabled veteran, Vietnam-era veteran or any other veteran who served on active duty during a war or in a campaign or expedition for which a campaign badge has been authorized).

University Policy is intended to be consistent with the provisions of applicable State and Federal laws. Inquiries regarding the University's nondiscrimination policies may be directed to the Affirmative Action/Staff Personnel Services Director, University of California, Agriculture and Natural Resources, 300 Lakeside Drive, 6thFloor, Oakland, CA 94612-3550; 510-987-0096. For information on how to obtain this publication and other ANR CS products, call 800-994-8849. 


\section{WARNING ON THE USE OF CHEMICALS}

Carefully follow all precautions and safety recommendations given on the container label. Store all chemicals in their original labeled containers in a locked cabinet or shed, away from foods or feeds, and out of the reach of children, unauthorized persons, pets, and livestock.

Confine chemicals to the property being treated. Avoid drift onto neighboring properties, especially gardens containing fruits and/or vegetables ready to be picked.

Mix and apply only the amount of pesticide you will need to complete the application. spray all the material according to label directions. Do not dispose of unused material by pouring down the drain or toilet. Do not pour on ground: soil or underground water supplies may be contaminated. follow label directions for disposing of container. Never burn pesticide containers.

PHYTOTOXICITY: Certain chemicals may cause plant injury if used at the wrong stage of plant development or when temperatures are too high. Injury may also result from excessive amounts or the wrong formulation or from mixing incompatible materials. Inert ingredients, such as wetters, spreaders, emulsifiers, diluents, and solvents, can cause plant injury. Since formulations are often changed by manufacturers, it is possible that plant injury may occur, even though no injury was noted in previous seasons.

Funding for this publication was made possible through a grant from the Elvenia J. Slosson Fund. 